\title{
THE ROLE OF AGRICULTURAL PRODUCERS IN BUILDING THE SOCIAL CAPITAL IN RURAL AREAS. COOPERATION OF PIG FARMERS FROM BABIN - CASE STUDY
}

\author{
Monika WESOŁOWSKA \\ Maria Curie-Sklodowska University \\ Faculty of Earth Sciences And Spatial Management \\ al. Kraśnicka 2cd; 20-718 Lublin \\ monika.wesolowska@umcs.pl
}

\begin{abstract}
Collective action is one of the most important ways of obtaining competitive advantage of an agricultural farm. This is confirmed by the experience of many countries leading in the development of the agricultural sector. Based on the selected example of the village of Babin, the author presents the cooperation of farmers in the scope of the sale of pig livestock, and identifies transformations in terms of the social capital resulting from the forms of team work. Attention is also drawn to the motives and consequences of collective action.
\end{abstract}

Key words: Agricultural producer groups, pork producers, Rural Development Programme, social capital, collective action.

\section{Introduction}

The rural areas of the Lubelskie Voivodeship are categorised as problem areas. The most frequently identified problems include considerable fragmentation of agriculture, agrarian overpopulation, hidden unemployment, depopulation of peripheral rural areas, and aging of the population. The unfavourable dispersed structure of farms is a factor potentially leading to the marginalisation of agriculture in certain regions, and even disappearance of agricultural activity. The predominance of small family-owned farms in the agrarian structure will probably not be subject to substantial changes in the perspective of approximately a dozen years. Higher efficiency and competitiveness of Polish agriculture require actions contributing to the improvement of its structure. It is particularly advisable to develop tools favouring consolidation of farms with low economic potential, as well as other instruments permitting the improvement of the commerciality of farms. Difficulties such farms have with reaching the economic scale ensuring sufficient income based on agricultural production justify supporting their revenues with public resources, and the process of their restructuring within the scope of activities of the Common Agricultural Policy of the European Union. Financing provides a chance for launching modernisation processes in agriculture. It also permits introducing socio-economic changes in rural areas. 
Poland has a competitive advantage in those production sectors which require significant labour and land inputs, and which are difficult to mechanise. The primary source of the competitive advantage of Polish farms involves lower costs of labour. Such costs, however, are continuously growing. Along with the bad area structure and relatively high contribution of persons employed in agriculture, this adversely affects their competitive capacity (Dobrowolski and Wesołowska 2010). It is also worth emphasising that the competitiveness of farms largely depends on the scale and direction of production, and the level of its specialisation. Polish agriculture is moreover distinguished by considerable regional variability of the economic results of farms. This is a consequence of the diverse concentration and intensity of production resulting from historical processes, and variable environmental conditions.

The important elements of strengthening the competitive position of the agricultural sector include: high quality of agricultural products obtained by means of environmentally-friendly methods, low level of environmental degradation, and promotion of activities integrating the agricultural producers.

The social capital is of paramount importance for the development of rural areas. It is defined as the potential for cooperation rooted in the interpersonal relations and social norms, which can bring benefits to individual persons as well as to entire groups. Abundance of social capital is manifested in bottom-up self-organisation of people. The types of relations include the so-called formally organised relations (Putnam 2008). High level of the social capital occurs when people establish good relations with the other members of the community, trust one another, and act collectively for the sake of improvement of the living conditions. In the economic sphere, this contributes to lower costs of concluded transactions or establishment of enterprises (Fukuyama 1997).

The objective of the article is to present cooperation of the farmers in the scope of the sale of pig livestock. The author draws attention to the motives and consequences of collective action. The research was conducted with the use of the interview method within the area of activity of one of the agricultural producer groups in Babin.

\section{Agricultural producer groups}

The experience of many countries leading in the development of the agricultural sector shows that collective action is one of the currently most important ways of gaining competitive advantage of an agricultural farm (Chlebicka 2008; Tomczak 2009). The term stems from the modern theories of collective action, and concerns activity undertaken by various sizes of groups of entities - people or organisations, sharing a common purpose, which is easier to achieve this way than through individual action. The efficiency of the groups and societies in undertaking collective action translates into their economic results, achieved level of wealth, as well as the social coherence (Ostrom and Ahn 2007; Olson 2012; Grodzicki 2015).

Agricultural organisations currently play an important role in the transformations of the rural areas and agriculture in Poland (Halamska 2008; Michna 2010). Support and development of any activities aimed at the activation of agricultural producers, undertaking common activities in the market, and popularising family-owned agricultural production lead to higher income gained by farmers and agricultural producers in their farms and 
enterprises. In many countries, cooperation of farmers in agricultural producer groups constitutes an important element of conquering the market. Agricultural producer groups in the European Community do not act single-handed. They develop a number of relations among each other at the regional and national scale. Therefore, they become an important partner for the authorities in the development and implementation of the agricultural policy. They create strong economic relations favouring the local development, and stabilise the situation in the labour market (Lemanowicz 2004). The experience of the countries with strongly developed producer organisations shows that by undertaking collective action, producers deal with more difficult management conditions, higher industrial and consumer requirements, and stronger competition more efficiently. In consequence, they maintain their income at a possibly high level (Halicka and Rejman 2001).

The basic idea in the development of groups of agricultural producers resides in undertaking common activities to meet the challenges of the competition-driven market economy. Cooperation in such a group should be always based on the principle of voluntary participation of its members, and on respect for the collectively arranged rules. The task of the producers is to develop products of the highest quality, and their preparation for sale. Farms producing low quality goods are excluded from the group. Due to the proper organisation and adjustment of production to the requirements of the recipient in terms of quality, quantity, and assortment, with simultaneous application of the rules of environmental protection at all stages of production, storage, and distribution of agricultural products, rgw farmers obtain a better position in the market, as well as a higher and more stable income. The adopted solutions allow agricultural producers to improve their activities with the application of the already existing human and investment potential in the scope of a group of producers selected with reference to a given product or group of products.

The producer groups provide new possibilities for activities, permitting the reduction of production costs and risk. The combination of the market offer of a number of farms multiplies their economic strength and possibilities of participation in the market. It also opens new sales channels that could not be used by single farms. It also strengthens the negotiation position in commercial contacts with the recipients of products and the suppliers of production resources (Czapiewska 2013).

In Poland, agricultural producer groups operate under the provisions of the act of 15 September 2000 on agricultural producer groups and their associations, and on the amendment of other acts (Journal of Laws No. 88, item 983 as amended). Agricultural producer groups can operate based on four legal forms: limited liability company, cooperative, society, or association. The act stipulates that members of a group can be natural persons, organisational entities without legal personality, and legal persons running an agricultural farm as defined in the provisions on agricultural tax, or operating within the scope of special sectors of agricultural production.

As compared with the countries of the old European Union, the number of groups associating farmers in Poland is still too low. For example, in France, as many as 68\% of producers associated in the breeding industry belong to agricultural producer groups, whereas in Poland, the contribution amounts to less than 2 percent of the potential producers (http://www.tvpparlament.pl). The situation is improving, however, largely due to the financial support from the Rural Development Programme, constituting a continuation of an activity initiated in the Rural Development Plan from the 2004-2006 period. In the 
years 2007-2013, MEUR 182.5 were allocated to the support of the new producer groups in RDP. In the current period of 2014-2020, the amount is MEUR 256.4. The support is dedicated to groups operating as micro, small, or medium enterprises. It constitutes a fixed percent of the value of net revenues of a group from sales of products or a group of products produced in agricultural farms of its members in particular years, and sold to recipients who are not members of the group or organisation. The support is granted in the period of the first five years of functioning of a group, and amounts to: in the first year $-10 \%$, in the second year $-8 \%$, in the third year $-6 \%$, in the fourth year $-5 \%$, in the fifth year $-4 \%$. The awarded financial assistance is intended to facilitate the establishment and functioning of the groups. In the last financing period (2007-2013), the agricultural producer groups benefitted from various forms of support, i.a. from the co-financing of investments, exemption from income tax and property tax, and preferential loans.

Due to the offered support, association into agricultural producer groups has become increasingly popular among farmers in Poland over the recent years. At the moment of accession of Poland to the EU, only 20 agricultural producer groups existed. At the end of 2015, 1317 agricultural producer groups were already entered in registers of the Voivodeship Marshalls (www.arimr.gov.pl). The largest number of agricultural producer groups functions in the Wielkopolskie, Dolnośląskie, and Kujawsko-Pomorskie VoivodeshipsVoivodeship, and the least in the Małopolskie and Świętokrzyskie VoivodeshipsVoivodeship (Fig. 1). The largest number of agricultural producer groups was established in the following areas: cereals and oilseeds, pork and poultry.

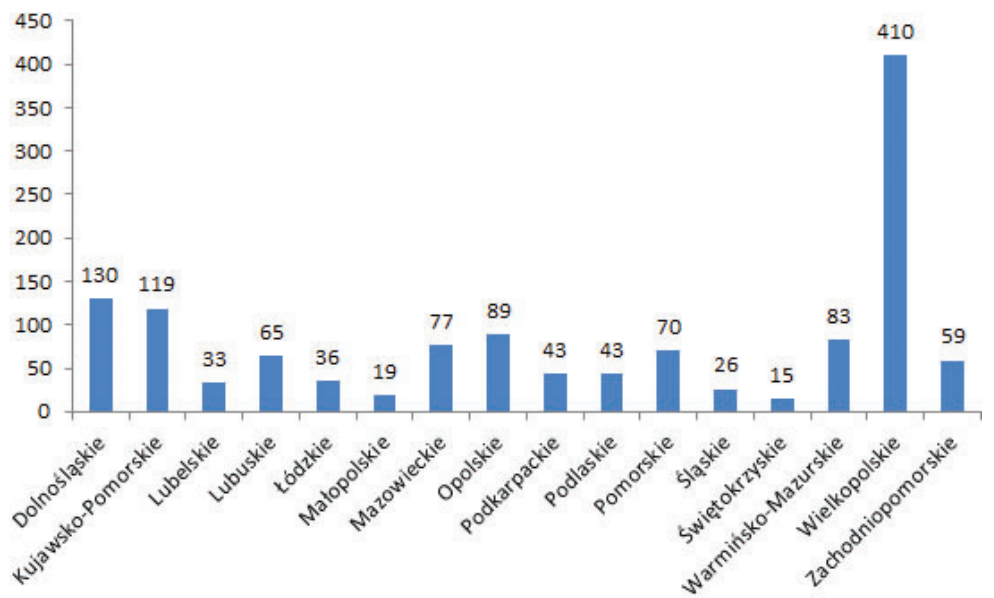

Fig. 1. Agricultural producer groups by voivodeships, 2015

Source: own elaboration based on the list of agricultural producer groups www.minrol.gov.pl

\section{Pork production in Poland}

Pork occupies an important position in the global meat market, including Poland. The share of pork in the global meat production and consumption amounts to approximately 42 percent, and in the EU approximately 50 percent. In Poland, the share of pork in the total meat production (including offal) amounted to 44 percent in 1212. In spite 
of a considerable decrease in slaughter meat production in the recent years, it remains a product preferred by Polish consumers (Fig. 2). The consumption of the meat remains at a relatively high level. In the years 2008-2012, approximately $42 \mathrm{~kg}$ of pork per capita was consumed. More pork than in Poland is consumed by a statistical citizen of Austria, Germany, Spain, Denmark, and Belgium (Kossakowska 2013). For the purpose of promotion of pork and pork products, the Pork Promotion Fund was established in 2009. Together with nine funds concerning other foods, it is administered by the Agricultural Market Agency. The resources of the Fund allow the related organisations to finance i.a. theirown contribution required when applying for subsidies from the EU budget for promotional and information activities.

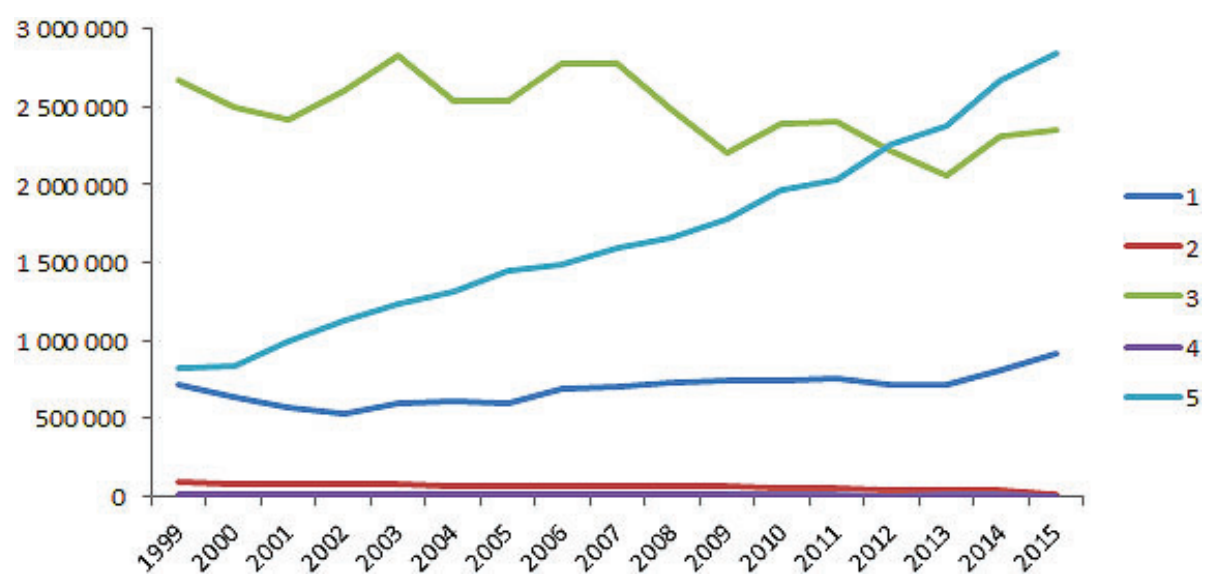

Fig. 2. Production of slaughter animals in Poland by species (in tonnes). 1 - cattle; 2 -calves; 3 - pigs; 4 - sheep; 5 - poultry

Source: own elaboration based on data of the Central Statistical Office.

In the eighties and nineties livestock breeding in Poland was fetured by high dispersion. More than 700 thousand farms existed at the time dealing with pig rearing and breeding. The period of political transformation in Poland was the beginning of the restructuring of the livestock production. The possibilities of contact with the EU member states, and initiating cooperation with breeder associations i.a. from Denmark, Spain, Holland, and Germany provided the Polish breeders of livestock with chances for an almost unlimited development. In the first years of production transformations, particularly in the individual sector, the centres of agricultural consultancy and agricultural chambers played an important role. Meetings and training for breeders were organised over the period.

The largest production of pigs is recorded in areas of traditional fattening in Poland: in the Wielkopolska and Kujawy regions (Fig. 3).

The modern trends in the Polish sector of pig production are disturbing. Livestock rearing currently takes place on individual farms (there are more than 250 thousand farms dealing with livestock production). This contributes to a very low level of rearing concentration. Poland has been systematically becoming one of the largest net importers of pork, pigs, and piglets for further fattening for several years. In 2013, farmers imported more than 3500 thousand piglets for further fattening, with a simultaneous fall in the 
number of sows to 800 thousand units. This results from a high dispersion of rearing pigs, whereas the market expects even batches of pigs for fattening. In order to meet the requirements of the market and European competition, concentration of livestock must occur, with simultaneous specialisation of production. A herd of sows permitting production of the absolutely minimum production batches, i.e. 200 individuals of piglets produced in one piggery within one week, is the smallest so-called recommended production unit. This corresponds with the optimal commercial batch (Potrowski 2014). Therefore, it seems justified to associate farmers in groups in order to meet the requirements of the European market.

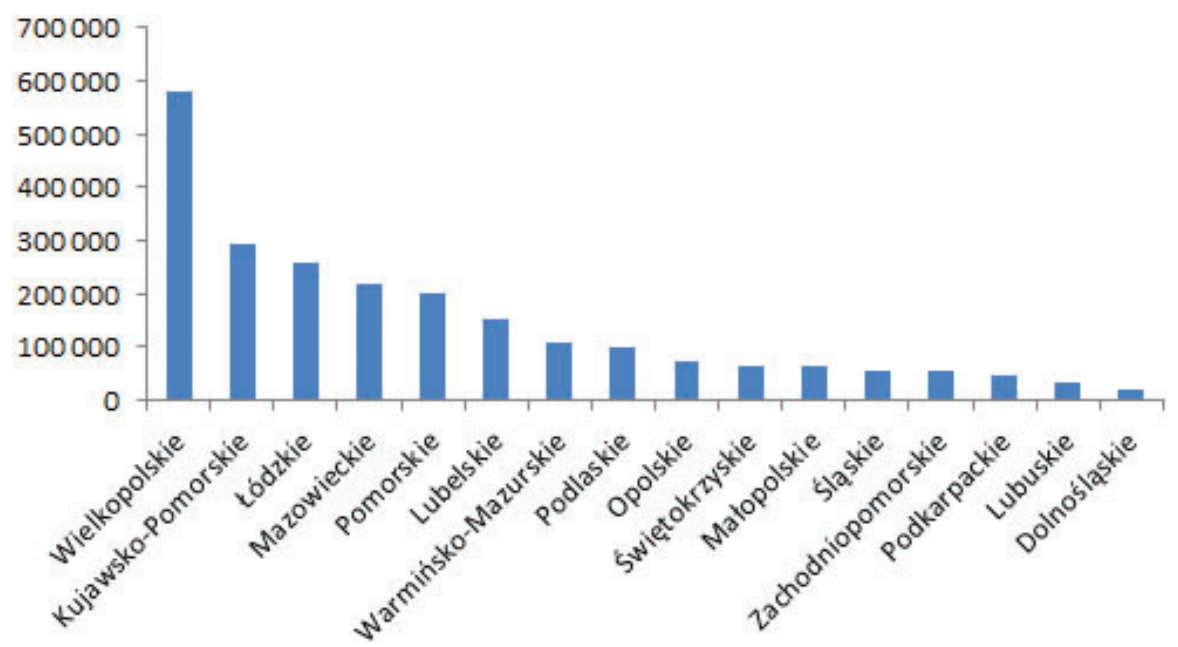

Fig. 3. Production of pigs in 2014 (in tonnes)

Source: own elaboration based on data of the Central Statistical Office.

\section{Cooperation of pig breeders based on the example of producer groups in the Babin village}

The Babin village is located in the Bełżyce commune in the Lubelski district. The Bełżyce commune is of a typically agricultural character, determined by the quality of soils. Soils developed from loess and silty formations of varied genesis are predominant, as well as slightly-loamy and loamy sands (Turski et al. 1994). Soils occurring in the area of the Bełżyce commune are categorised as good and very good, and 75 percentof arable land consist of bonitation class III and IV soils. Due to the good soil and climate conditions, specialisation of agricultural farms is possible. The dominant profiles of plant production include cereal production and mixed plant production (cereals, root crops, oil seed crops). The favourable natural conditions and relevant labour resources also contribute to the development of various directions of livestock rearing. The primary direction of meat production is pig rearing. The animals can be relatively easily provided with appropriate cereal-potato fodders, and the short cycle of fattening ensures fast return on investment. A considerable asset of the commune is its convenient location in terms of transport, in the zone of direct vicinity of Lublin, making Bełzyce the food supplier of the city. 
In spite of the favourable environmental conditions, the global production per 1 ha of arable land in the entire Lubelskie Voivodeship is lower by approximately 15 percent than the national average. The structure of farms is dominated by those with low profitability - the majority of them reaches up to 8 ESU (May 2011). Therefore, the Lublin region shows unused potential in the scope of agricultural productivity, and therefore production commerciality. The agricultural census in 2010 revealed the functioning of 2258 agricultural farms with unfavourable agrarian structure in the commune and town of Bełżyce. Small agricultural farms are dominant. Their number amounts to 1656 (39\% - 1-5 ha, 35\% - up to 1 ha). Large farms (of more than 15 ha) are scarce, amounting to only 101 (4\%). Therefore, one of ways to increase the commerciality of agriculture is associating farmers in producer groups. Organised agricultural producer groups can compete in the market with large farms. They can also become partners for wholesale markets, processing industry, export, and distribution platforms of large-area chain stores.

In March 2006 the pioneer Cooperative Producer Group Atut was established (Spółdzielcza Grupa Producentów Atut) in the Bełżyce commune, in the Babin village. The objective of the cooperative stipulated in its Articles of Association was to provide, on behalf of its members and to their benefit, conditions for the development of pig production in their farms through enabling the sale of the produce at the most advantageous prices possible, and incurring the lowest possible costs. From the beginning of its existence, the primary activity of the group involves the purchase and sale to processors of pigs produced by the members of the Cooperative. The implementation of the objective of the group can be considered in the categories of collective interest. It brings benefits to all members of the group. This activity is supplemented by the purchase of pigs from farmers who are not members of the Cooperative, the sale of fodders, fertilisers, and seeds. The Articles of Association stipulate six primary objectives of the Cooperative:

1) adjustment of agricultural production to the market conditions,

2) improvement of management efficiency,

3) production planning with particular consideration of its volume and quality,

4) concentration of supply, and organisation of the sale of agricultural products,

5) providing members with production resources at the lowest prices possible

6) protection of the natural environment.

In the beginning, the activity of the group was conducted in a base leased from the Agricultural Club in Babin. In July 2008, the base was purchased, and became the property of the Cooperative. At the beginning of its existence, the Cooperative employed one person. It currently has five employees. The company works six days a week in a single shift. The scale of its sales is more than 12 thousand pigs and the sale of fodders and fertilisers for an amount of approximately MPLN 3.

The development of the activity of the Cooperative was possible due to European Union funds. Since the beginning of its existence, the group obtained more than PLN 600,000, allocated to various purposes, and particularly investments. The groupbenefitted from the assistance under measure "Establishment and development of micro enterprises" within the scope of the Rural Development Programme for the years 2007-2013. The largest investment implemented with the support of the EU funds was the purchase of 75 ares of land from the liquidated Cooperative of Agricultural Clubs together with the office-workshop building with a garage $\left(711 \mathrm{~m}^{2}\right)$, social-office container $\left(9 \mathrm{~m}^{2}\right)$, and a paved area $\left(2015 \mathrm{~m}^{2}\right)$. 


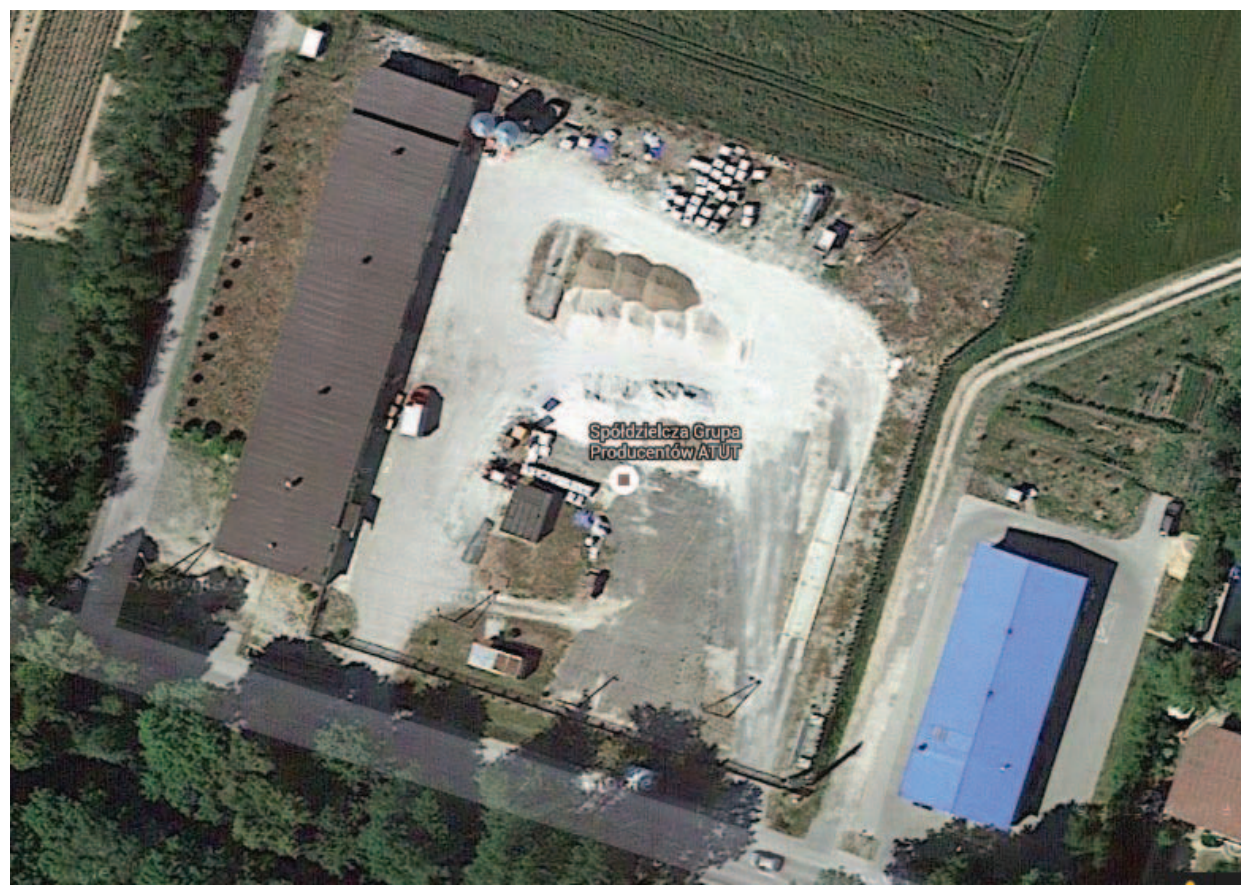

Photo 1. The premises with buildings belonging to the Cooperative of Agricultural Producers Atut in Babin Source: https://www.google.com/maps/@51.1761523,22.3361864,123m/data=!3m1!1e3?hl=pl

For the purpose of expanding the scope of activities by various services supporting plant production, i.a.: transport of manure to fields, the sale of lime fertiliser complete with the service of its spreading, performance of measurement of agricultural plots, and providing services of spreading lime fertiliser, new machines were purchased with the assistance of EU funds. The machines include: a weighing facility, slurry spreader, fertiliser spreader, forklift, and high pressure cleaner, as well as a GPS device for measuring the area of fields. At the beginning, machines were leased to members. Today, they are operated by a driver. Due to this, the equipment is less prone to failures. The members of the Cooperative use the equipment at the cost of the fuel.

The group currently associates 42 agricultural producers, and the mean production per farm amounts to 200 pigs for fattening annually. Due to the association and organisation of common sales, the producers have been obtaining the same prices for pigs in the recent years as the larger suppliers. Livestock from Atut features mean meatiness of 57-58 percent\%, and is relatively even. The Cooperative has a signed contract with slaughterhouse tmeat, where it supplies the majority of the produced livestock. The excess is sold outside the agreement. The group also organises the sale of pigs for fattening for farmers not belonging to the group. The group earns from 5 to 10 PLN per sold pig in the scope of payment for the organisation of delivery. Due to the common sales, the farmers belonging to the Cooperative not only obtain a price higher by $0.40-0.50 \mathrm{PLN} / \mathrm{kg}$, but also earn money directly on the organisation of sales.

Benefits from the membership in an Agricultural Producers' Group are particularly of economic importance. This confirms the findings from other areas of Poland. The study 
by Knecht (2012) conducted among Agricultural Producers' Groups, particularly the producers of pig livestock, evidenced the following:

- Farmers acting collectively feel more confident and are more willing and motivated to invest in farms for the purpose of improvement of the quantity and quality of livestock sold to recipients.

- Producers involved in Agricultural Producer Groups effectively compete for higher prices of livestock and better conditions of sales.

- In negotiations with the recipients, the members of the producer groups are usually able to obtain a higher price for livestock than the market price.

- Organisation of agricultural producers is of strategic importance in the case of the production and sale of high quality livestock. Its high quality (meatiness) ensures continuous sale, profit, and possibilities of development and expansion of agricultural farms.

- An important effect of the resulting entities is the creation of new distribution channels and the organisation of sale of livestock through the group.

In 2008, group Atut undertook cooperation with other producer groups within the scope of cooperation of the Pork Producer Groups of Central-Eastern Poland. The cooperation involved six producer groups dedicated to the production of pigs east of the Vistula River. The development of the forms of cooperation initiated on a bottom-up basis, and coordination of activities between the individual producer groups is a relatively new phenomenon in Poland, but it facilitates the achievement of many objectives. The association of pork producers from eastern Poland declared cooperation for the achievement of objectives such as:

- introduction of independent post mortem assessment of meatiness of carcasses in slaughterhouses,

- introduction of the obligation to label the meat and meat products,

- facilitation of granting bank warranties to the producer groups by state institutions within the scope of capital initiatives involving e.g. an attempt to purchase the existing meat processing plants by producer groups,

- facilitation of payments between the slaughterhouse and the producer group through obligatory 14-day time of payment,

- control of food products on sale.

In 2009, the Cooperative also joined the newly established National Association of Agricultural Producer Groups - Commercial Chamber (Krajowy Związek Grup Producentów Rolnych - Izba Gospodarcza), associating 96 agricultural producer groups from various sectors of the market. The primary tasks of the association include the representation of the associated groups before the governmental authorities, ensuring conditions for the versatile economic development of the groups, development of a forum for exchange of experience through the organisation of meetings, training, study tours, assistance in running agricultural producer groups, development of cooperation between groups, and popularisation and support in the establishment of agricultural producer groups (www. kzgpr.pl).

The cooperation of farmers creates the social capital favouring the implementation of new undertakings and projects. Although the group is primarily involved in market competition and takes risk in everyday activity, it also implements non-economic objectives, and its members show motivation beyond the will to obtain remuneration or profit 
(Defourny, Nyssens 2013). Atut supports various local initiatives, among others a family picnic organised by the Elementary School in Babin, Open Days organised by LODR in Końskowola, a regional harvest festival, and agricultural fairs. It has been a co-organiser of the "Pork Festival" for five years. The initiative involves o.a. the organisation of a culinary competition and shows of artistic groups (Fig. 4). Apart from the promotion of pork products in various forms, the event provides a perfect opportunity to present the achievements of Agricultural Producer Groups. The undertaking also involves the organisation of a scientific conference with lectures, for instance on the African swine fever (ASF) as well as feeding pigs with the application of alternative feed materials. The access to the conference is free.

In 2013, based on the Agricultural Service-Commercial Cooperative ATUT, two new Producer Groups were established, namely the Cooperative of Farmers "KABAN" and "KABAN BIS". The former associates farmers with own fixed asset livestock producing pigs for fattening with their own piglets. Production is performed in a closed cycle. The latter group runs production in an open cycle. Farmers from the group purchase piglets and pigs for further fattening. Both of the groups associate more than 40 members, and their annual production varies from 18 to 20 thousand pigs for fattening annually. The groups initiated cooperation with the Agricultural Service-Commercial Cooperative "Atut" in Babin which offered the lease of office facilities and logistic support to members of the groups.

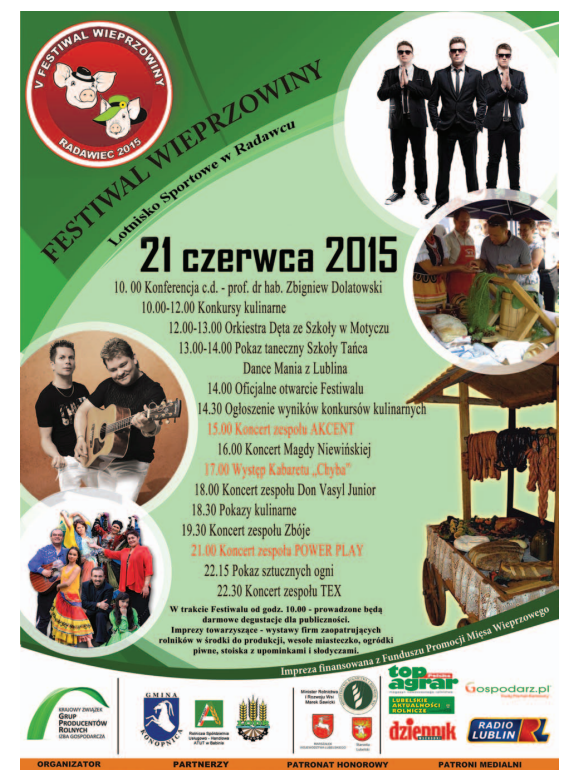

Fig. 4. Poster promoting the Pork Festival

Source: http://www.kzgpr.pl/wiadomosci/414.html

All the producer groups from Babin are in close cooperation with i.a. the LODR in Końskowola, the Marshall's Office of the Lubelskie Voivodeship, and the National Cooperative Board, benefitting from consultancy services and assistance offered by these institutions. They are planning common future activities, also using money from the EU funds for investments. 
Unfortunately, in spite of the economic success of the members of the analysed cooperative, several of its members were excluded due to the sale of livestock outside the activity of the group. One of the basic rules of collective action was broken, namely trust which is an important feature of the social capital. Unfortunately, as was noticed in the Strategy... (Strategia... 2012), the social capital currently takes the forms of survival and adaptation instead of openness, creativity, and action for the sake of good and community. It is also difficult for new farmers to join a group. This results from the aforementioned low level of trust. Research conducted by the Public Opinion Research Centre confirms the low level of trust among Poles, and a high level of mistrust in interpersonal relations, much lower than in other European nations. As evidenced by Zakrzewska (2013), the feeling of trust is strongly correlated with social and demographic parameters. Residents of rural areas are considerably less trustful than residents of cities. Low level of trust is also characteristic of young persons (aged 18-24). Among vocational groups, farmers disclose the lowest level of trust.

\section{Conclusions}

Although agriculture in the Lubelskie Voivodeship, featured by an unfavourable agrarian structure and high dispersal of arable land, does not take full advantage of the environmental conditions favouring agricultural production, it is possible to make it more efficient and competitive. An activity consolidating farms with low economic potential is associating farmers in agricultural producer groups. Integration activities are supported also from the financial resources coming under the Common Agricultural Policy of the European Union.

An example of the development and economic strengthening of farmers may be seen in the activity of the Agricultural Producer Group Atut in Babin. Owing to the support of financial resources from programmes of the European Union, the group made a number of investments permitting the development of the members of the cooperative, and paid provision of services to farmers who do not belong to the group. Associatipn of the farmers also resulted in signing a contract with a large recipient of pork, and obtaining a higher amount from the sales of livestock.

In spite of the low level of trust for collective action among the residents of rural areas, new forms of cooperation appear. The success of the producers from Atut was recognised by the local community, and resulted in the establishment of other producer groups. Groups from Babin undertook to conduct common activities leading to an enhancement in their competitiveness in the market, and therefore to obtaining greater economic benefits. Such a declaration of cooperation strengthens the social capital of the village. Activities are also initiated which do not translate directly into economic benefits, but unify the rural community (e.g. organisation of gatherings). Therefore, one of the intangible benefits resulting from the functioning of the agricultural producer group is also the activation of the local community. 


\section{References}

Chlebicka A., 2008, Ekonomiczno-społeczne uwarunkowania rozwoju grup producentów owoców i warzyw w Polsce, SGGW, Warszawa.

Czapiewska G., 2013, Grupy producentów rolnych w rozwoju obszarów wiejskich Pomorza, Acta Universitatis Lodziensis, Folia Geographica Socio-Oeconomica 13, pp.165-178.

Defourny J., Nyssens M., 2013, Social innovation, social economy and social enterprise: what can the European debate tell us?, [in:] F. Moulaert, D. MacCallum, A. Mehmood (eds.), The international handbook on social innovation: collective action, social learning and transdisciplinary research, Cheltenham.

Fukuyama F., 1997, Zaufanie. Kapitał społeczny a droga do dobrobytu, PWN, Warszawa-Wrocław.

Grodzicki M., 2015, Dlaczego grupom udaje się podejmować działania? Przedstawienie teorii dziatań zbiorowych Elinor Ostrom, Ekonomia Społeczna, 1, pp.66-78.

Halamska M., 2008, Organizacje rolników: bilans niesentymentalny, [in:] M. Halamska (ed.), Wiejskie organizacje pozarzqdowe, IRWiR PAN, Warszawa, pp 103-133.

Halicka E., Rejman K., 2001, Przedsiębiorczość rolników wobec integracji z Uniq Europejskq - tworzenie grup producenckich, [in:] K. Gutkowska and J. Ozimek (eds.), Rozwój przedsiębiorczości wiejskiej w perspektywie integracji z Uniq Europejskq, Wyd. SGGW, Warszawa, pp. 96-122.

Knecht D., 2012, Grupy producentów rolnych w Polsce ze szczególnym uwzględnieniem producentów trzody chlewnej. Stan i perspektywy rozwoju, Monografie, CLIII, Uniwersytet Przyrodniczy, Wrocław.

Kossakowska J., 2013, Wybrane czynniki wpływajqce na poziom konsumpcji wieprzowiny w Polsce (1990-2012), Biuletyn informacyjny, 2, Agencja Rynku Rolnego, Warszawa, pp. 2-13.

Kostro K., 2005, Kapitał społeczny w teorii ekonomicznej, Gospodarka Narodowa, 7-8, pp. 1-28.

Lemanowicz M., 2004, Grupy producenckie i marketingowe i ich wpływ na pozycje konkurencyjnq rolników na rynku, Acta Scientarium Polonorum, Oeconomia, 3.

Maj H., 2011, Rolnictwo [in:] W Janicki (ed.), Województwo lubelskie. Środowisko-społeczeństwo-gospodarka, pp. 138-152.

Michna W., 2010, Organizacje wiejskie i rolnicze oraz ich rola w rozwoju obywatelskiej demokracji i krajowej gospodarki, IERiGŻ PIB, Warszawa.

Olson M., 2012, Logika działania zbiorowego. Dobra publiczne i teoria grup, Wydawnictwo Naukowe Scholar, Warszawa.

Ostrom E., Ahn T.K., 2007, The meaning of social capital and its link to collective action, Workshop in Political Theory and Policy Analysis Working Paper, W07-19.

Porowski M., 2014, Polska produkcja trzody chlewnej - przeszłość, teraźniejszość, przyszłość, Magazyn hodowcy, 3, pp. 12-20.

Putnam R.D., 2008, Samotna gra w kręgle. Upadek i odrodzenie wspólnot lokalnych w Stanach Zjednoczonych, Wydawnictwa Akademickie i Profesjonalne, Warszawa.

Strategia rozwoju kapitału społecznego, 2012, Komitet Stały Rady Ministrów, Warszawa.

Tomczak P., 2009, Grupy producentów rolnych jako nowe formy zespołowego działania na polskiej wsi, Studia Obszarów Wiejskich, 17, pp. 201-212.

Turski R., Uziak S., Zawadzki S., 1994, Schematyczna mapa gleb Lubelszczyzny, Lubelskie Towarzystwo Naukowe, Lublin.

Wesołowska M., Dobrowolski J., 2010, Zróżnicowanie przestrzenne absorpcji środków UE przez polskie rolnictwo w 2008 r., Studia Obszarów Wiejskich, 24, pp. 43-57.

Zakrzewska M., 2013, Uwarunkowania rozwoju kapitału społecznego w Polsce, Studia i Prace Wydziału Nauk Ekonomicznych i Zarządzania, 32, pp. 79-96. 